\title{
MEDIA LITERACY COMPETENCY-ORIENTED LIFE SKILLS FOR HIGH SCHOOL TEACHER IN THE CITY OF BANDUNG IN THE FACE OF MEA
}

\author{
Firman Aziz ${ }^{1)}$ \\ ${ }^{1)}$ Universitas Pendidikan Indonesia \\ Email: firman.aziz@upi.edu
}

\begin{abstract}
Use good media mass media as well as electronic media increases over time, especially with the presence of new media that is able to collect, process, and exchange information quickly. Research literacy competency media beorientasi life skills aims to describe the media literacy competency-oriented life skills which belonged to the high school teacher in the city of Bandung. Research methods using a descriptive qualitative approach method. The expected results are: (1) the discovery of the level and type of media literacy and competency (2) discovery of quality, factor endowments, and restricting the media literacy competency-oriented life skills teachers HIGH SCHOOL in Bandung. The results of the analysis of the data shows that the competence-based media literacy-oriented life skills teacher HIGH SCHOOL city of Bandung were still on secondary media literacy.
\end{abstract}

Keywords: Competence, Media Literacy, life skills

\section{INTRODUCTION}

The presence of technology, information, and communication has changed the orientation of the life of mankind. The ability of technology, information, and communication in providing everything necessary for the continuity of human life and comfort make the technology, information, and communication of successful entry into all aspects of life. Language activities in relation to the activities of the write medium in order to understand any form or manifestation of technology, information, and communication as one of the activities that supports the survival of human beings, is now no longer an unbounded keaksaran activity deals with the media physically write medium (paper). Media write medium is now combined with the media Vantage-listen or audio-visual digital media as well as the shape of the stroke technology. The presence of technology, information, and communications have influenced various aspects of the dynamics of human life began way of thinking, a way of feeling, to the way human behave very pronounced will "touch" technology, information, and communication. Man that was struck was not what dikreasikan can be turned into a hostage (technology of determinism). This condition caused no other strong influence and the role of technology, information, and communication are available.

Influence of media on the battle of life must be followed by the preparedness community. Activities interact and communicate, who had limited activities keaksaran bermedia paper and unbounded. Now such a significant shift towards activities that require an understanding of multimedia, multimodal, and multimodel along leaps and bounds of civilization that are generated by the entry of technology into the realm of information and communication. Cases of misuse of the media emerged as an indicator of society's unpreparedness in the face of technological development, information and communication. The literacy abilities of unbounded on the activities of the physical write medium must be really terkuasai very well. Alphabet literacy or literacy must be immediately shifted with the literacy level of the media towards may or media literacy. No longer write medium unbounded but understand and productive, participating actively in order to not so principals or even victims are harmed due to misuse of information and communication media.

The abuse cases prove that the community has not been able to absorb the information and convey information well through the media. This is related to the literacy ability has not been good among the public. Some perpetrators of cases of abuse of the media is the teacher and the student. This proves that as an educator, there are many teachers who do not yet have a good media literacy ability. This imposes on learners. Lack of literacy education from teacher to learner led pesereta learners don't have good media literacy ability, finally the learners to become pekaku in the misuse of media information.

Media literacy is becoming important to prepare the audience for the media to be more sensitive and more anticipatory when coming into contact and the influence of media on the other. Media literacy abilities already possessed by the appropriate teacher. It is aligned with the content of the Government Regulation (PP) number 74 in 2008 about the teacher who States that teachers should have the competence, the competence of personality pedagogy, social competence, and professional competence. Aspects of competence that should be owned by the teachers, one teacher's competence with regard to 
the pedagogic competency is media literacy, i.e. the utilization technology of learning by teachers or social competence, that teachers need to use information and communication technology are functional. The contents of the PP Number 74 in 2008 about the Teacher became one of the runways, the teacher should have a good media literacy the competence to develop the profession of seoptimal possible.

HIGH SCHOOL teachers are educators in the secondary high school. High school teacher is an educator who plays a major role in the formation of the character of learners. With good media literacy ability, teachers as educators, will absorb, deliver, and make good information. This research is early research of advanced research, namely literacy education for HIGH SCHOOL teachers. On this initial research, researchers want to chart the first literacy abilities of high school teacher in the city of Bandung, based on the level, type, quality, memegaruhi factors, as well as the availability of facilities and infrastructure supporting media literacy competencyoriented life skills teacher HIGH SCHOOL in Bandung.

\section{The Study Of Theory}

Understanding Of Media Literacy

The definition of media literacy, according to Buckingham and Livingstone using the trikotomi approach covers three areas, namely, media literacy means: (a) have access or facilities and infrastructure to the media, (b) understand the scope of the media, and (c) create/express yourself by using media (Darmasuti, 2013; Amalia, 2013). In General, media literacy is the ability of a person controlling influence the content or message of media on their lives. Irianto (2009, p. 68), specifies the media literacy activities include activities of accessing, analyzing, evaluating, and produce content or message media. This means that media literacy is a person's ability to use various media to access, analyze, evaluate, and generate information for various purposes. Someone will be influenced by the media around, good media content from television, film, radio, music, newspapers, magazines, even the internet can now be accessed via a cell phone. It happens in everyday life. According to Rahardjo (2012) the things that are important from a media literacy, among them "... the media literacy encourages the emergence of critical thinking from the public against programs that served the media, media literacy also allows the creation of ability to communicate are competent in all forms of media, being proactive rather than reactive in understanding media programs ... ". Thus, media literacy is directly related to the problem of the skills, knowledge, and competence.

The Main Elements Of Media Literacy

The main elements of media literacy there are six, namely (1) awareness of the impact of the media; (2) an understanding of the process of mass communication; (2) strategies for analyzing and discussing media messages; (3) understanding of media content as a text that gives an insight into the culture and life; (4) the ability to enjoy, understand, and appreciate the content of the media; (5) an understanding of the ethical and moral obligations of media practitioners;(6) skills development proper and effective production. (The first five elements by Art (1995). Two additional elements by Stanley j. Baran, 1999, pp. 49 - 54). The types in Media Literacy

There are two media literacy, i.e. the type of media literacy based on the destination media include (1) media literacy in a broader sense, compared to the media literacy of the word ' media literacy ' forms of literacy for the literacy activities of literacy. However, the equivalent of the word literacy does not reflect the major elements that literacy is not enough to just being able to read and understand text or discourse. Media literacy in the broad sense is still defined as a written media literacy in the content or print newspapers and the like. (2) media literacy in the sense of narrow, generally media literacy is the ability of an intelligent audience in utilizing media and can be applied to all individuals. Meanwhile, in the narrow sense, media literacy, still dwelling on certain media, i.e. the media audiovisual-based or informative has more to do with television. It is still we see in many media literacy in African-American activist site or foreign media literacy which showed that it was primarily intended for television media. Of course now the pop media literacy has relatively the same understanding that media literacy is applicable for all types of media, both old media or new media, both print and electronic (Amalia, 2013). (3) new media literacy, is the effect of advances in technology in particular. Digital media literacy is the conception of the enclosing skills and understanding for media based multi-dimensional, mutlimodel, as well as multimedia in between internetbased media, computer-based media, and media-based cell phones. Digital literacy is reinforced with the understanding that new media messages have consequences at the personal and dynamic public, the contents of the message content and new media are converging, and new media are able to liaise on participant communication from anywhere (social media).

The second type, i.e. the type of media literacy based on the level of proficiency that is trying to appear include the following matters: (1) the initial level of media literacy, media literacy is usually in the form of the introduction of the media, especially the impact of positive and negative potential produced by the media are presented; (2) intermediate media literacy aims to grow in proficiency understand, understand, and apply the messages that are presented from the media; (3) advanced media literacy, media literacy in the outer bore of know-how to understand media ranging from the planning up to the production of messages, the structure of knowledge against the media are relatively complete, critical understanding and on the level of action, e.g., advise on certain media and criticized certain media (Amalia, 2013). In relation to the life skills literacy media type based on the level of life skills who want to appear is the personal skills, social skills, academic skills, and competence of the Polytechnic in the form of a reflection of teacher professionalism.

Media Literacy Activity Skills 
Understand and bring up individual skills in using the media is the main goal of the literacy activities in the media. This goal is more important when compared with the aim to introduce the media or even to grow a critical understanding of the media. There are seven skill or ability that will emerge from the media literacy activities: analyze, assess, classify, induces, mendeduksi, synthesize, mengabstraksi (Potter, 2008). Such skills should also be strengthened with media literacy aspects according to Art (1995, p. 13), i.e., process, context, framework, production value. Based on the activities of the media literacy competencies has been mentioned by Potter (2008) and Art (1995), media literacy competencies that appear on research literacy competencies, namely media that cover the activities of accessing, analyzing, evaluating, and producing content/media messages (Irinato, 2009, p. 68). The fourth activity is the outline that represents the media literacy competence in theory Potter (2008) and Art (1995). Life Skills

Skills to manage and solve the problem of life is an absolute must-have skills of humans in ensuring continuity and comfort his life. Skilled or qualified to be an indicator of the success of the education given to someone. Skills or abilities that are used in living a life that is known for its istililah life skills.

Life skills are the skills possessed someone to boldly face the problems of life and the life of graceful without feeling depressed, then proactively and creatively seek and find a solution so that finally was able to overcome it (Supriatna, 2007). Based on the understanding of media literacy competency-oriented life skills at this high school teacher should be able to contribute to the improvement of the ability, willingness, and skills needed by a high school teacher to keep continuity of learning (live) and self development especially development concerning teachinglearning cycle in order to increase the skills of learners one on media literacy skills.

Supriatna (2007) outlines regarding the abilities, ability, and skill that is intended, namely (1) the ability is the realisation of the nature of cognitive life skills, (2) is capable of realization of life skills which are more affective, and (3) skill is the realisation of life skills which are psychomotor. Life skills include some basic capabilities, i.e., personal skills, social, academic, and Polytechnic (Marwiyah, 2012). The MoE life skills grouped into two, namely that life skills are generic (generic life skills) include personal skills (personal skills) and social skills (social skills). Life skills which are specific (specific life skills) includes academic skills (academic skill) and Polytechnic prowess (vocasional skills) (Supriatna, 2007).

As for life skills in the context of media literacy competence in these researchers include the following skills.

a. Personal Skills

Personal prowess in this study specifically is the ability to use and leverage the media to mengoptimalisasikan themselves, improve insight, knowledge, and abilities of self. Tecermin of personal skills and capabilities the ability to access, analyze, and evaluate the issues, problems, or a phenomenon produced by the information, ideas, or ideas on the process and results of media literacy. Then, convert the media content into products that can be utilized to support the learning process and learning.

b. Social Skills

Social skills in this study specifically is the ability to use and leverage the media to establish cooperation and communication with the general good relationship between educators and learners, educators and educators, educators and educational personnel, educators and environmental educators, educators, students and parents as well as educators and the community.

c. Academic Prowess

As for his academic prowess in this study specifically is the ability of teachers in using and utilizing the media to hone the Customs and scientific capabilities to enhance the learning process. Utilization technology of learning also maksuk in it technology media utilization in the field of information and communication are the Foundation of kompetesi media literacy.

d. Proficiency Polytechnic

Polytechnic skills include more specific capabilities contribute to the field of expertise of the teacher as a professional profession or skills related to the professional competence of the Polytechnic should posses as a form of teacher professionalism. Polytechnic prowess in this study specifically is the ability of teachers in using and utilizing the media or media content to improve the Professional (teacher).

\section{METHOD}

The methods used in this research is descriptive qualitative approach method. The qualitative approach used in this study is taken from Creswell (1994, p. 177). Researchers put the qualitative approach, since it is expected to be more revealing view of respondents high school teacher. Descriptive analysis techniques used to study further data and interpreted so as to produce a summary of comprehensive, relevant, and accurate, and relevant. Dekriptif analysis technique used is the percentage of engineering Sugiyono (2013). The population of this research is the high school teacher se-Bandung. This research sample taken based on a combined area of passing grade category (GW) academic HIGH SCHOOL line of Bandung city 2016. A sample of teachers in three schools that were taken randomly from the population. This is done so that the data obtained are accurate.

Media Literacy Level Of Competence-Oriented Life Skills Media literacy Competence levels of initial Of the research data obtained number percentage level of awareness of the impact of the media in human life as a main subject the user or users of the media, especially the high school teacher of Bandung city, amounting to $76 \%$ of expected awareness scale (100\%). 


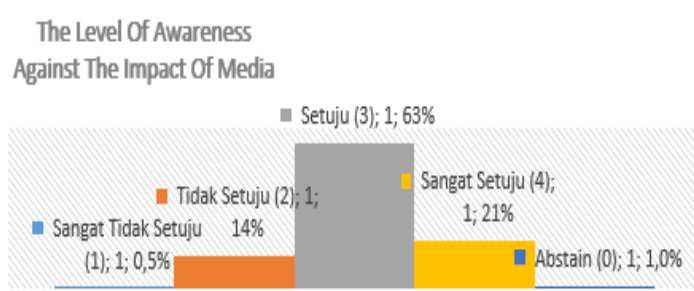

-Sangat Tidak Setuju (1) $=$ Tidak Setuju (2) $=$ Setuju (3) $=$ Sangat Setuju (4) $\quad$ - Abstain (0)

\section{Gambar 1 Persentase Tingkat Kesadaran Terhadap Dampak Media}

As for the description of the percentage level of awareness of respondents against the impact of the media in more detail per aspects of media content as follows: percentage of the level of awareness that media content can (1) affects the idea or the idea of its users amounting to $88 \%$; (2) affects the needs of its users, of $85 \%$; (3) add insights and new science users, amounting to $84 \%$; (4) the emotional feeling or affect its users amounting to $80 \%$; (5) raises the question or the issue of new users, amounting to $78 \%$; (6) affect the chance of its users, of 77\%; (7) affect decisions and habits of its users, amounting to $76 \%$; (8) certain goals and inculcate, 76\%; (9) affects the viewpoint and the mindset of users, amounting to $71 \%$; (10) to produce a deal, amounting to $70 \%$; (11) affect the behavior and actions of its users, amounting to $69 \%$; (12) give rise to disputes, amounting to $67 \%$; (13) affect the confidence of its users, amounting to $63 \%$.

Media literacy Competence levels of intermediate

Access the Skills of media messages

Based on data collected from the respondents obtained the percentage of skills to access media content on a high school teacher of Bandung city, amounting to $73 \%$ of the expected access skills scale (100\%). Figure 2 here's a perscale rician frekuentatif activities to access the media.

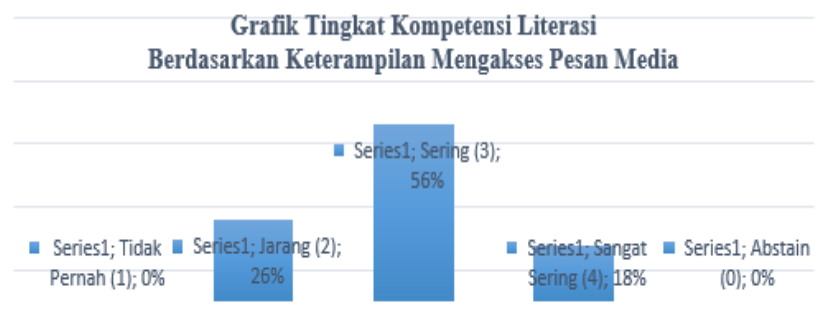

\section{Gambar 2 Persentase Frekuentatif Kegiatan Mengakses Pesan Media}

Activities to access the media message in Figure 2 are intended to describe the skills to access the media as one of the activities within the competence of the media literacy which (1) using social media to communicate with seprofession, with a percentage of $80 \%$ frekuentatif (representation of social skills); (2) accessing the various media to add insight and knowledge, with the percentage of frekuentatif amounted to $79 \%$ (personal skills representation); (3) read the latest issues of information, with the percentage of frekuentatif amounted to $79 \%$ (representation of social skills); (4) to access the media as additional materials and information for teaching, with the percentage of frekuentatif amounted to $79 \%$ (Polytechnic prowess representation); (5) access medium for sharing learning design products (RPP, Syllabus, teaching Media, etc.), with a percentage of $71 \%$ frekuentatif (representation skills Polytechnic); (6) look for things that can be of assistance to our daily lives, with the percentage of frekuentatif of $69 \%$ (personal skills representation); (7) monitoring of information on regulations and legislation in the utilization and use of media, with a percentage of $64 \%$ frekuentatif (representation of academic skills); (8) access the journals research results, with a percentage of frekuentatif of $63 \%$ (representation of academic prowess). The skills to analyze media messages

Middle-level literacy competency, which was excavated from the skills to analyze media messages obtained as a percentage of the skill to analyze media content on a high school teacher of Bandung city, amounting to $65 \%$ of the skills scale analyzes the media messaging expected $(100 \%)$.

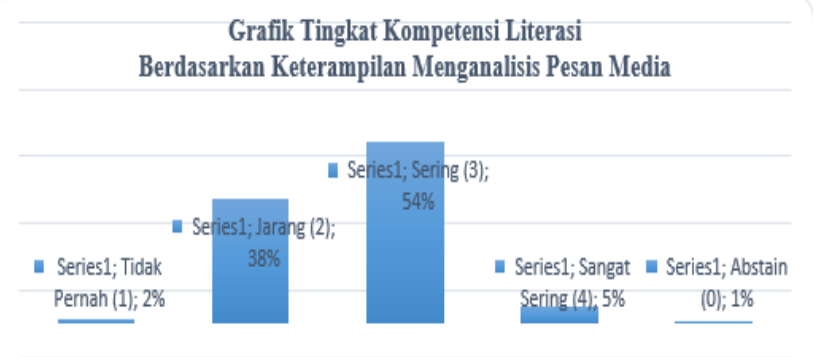

Gambar 3 Persentase Frekuentatif Kegiatan Menganalisis Pesan Media

Activities analyse media messages to describe the skills to analyze the message content or media as one of the activities within the competence of the media literacyoriented life skills which (1) review the truth (relevance) and benefiting (the credibility of) the source of the news, with the percentage of $70 \%$ frekuentatif (representation of academic skills); (2) identify the media content that is not appropriate to the learners, with the percentage of frekuentatif of $69 \%$ (Polytechnic prowess representation); (3) analyze media distimulus by personal inclination or interest in the topic, with the percentage of frekuentatif amounted to $66 \%$ (personal skills representation); (4) analyze media content with the point of view of religious values, ethics, and morality, with the percentage of frekuentatif of $64 \%$ (personal skills representation); (5) to feel angry, upset, sad, happy, enthusiastic, emotional and other perceived according to what myself and others after reading a media content, with the percentage of frekuentatif 
of $63 \%$ (the representation of social skills); (6) send information/news as material for discussion, with the percentage of frekuentatif by $60 \%$ (the representation of social skills).

\section{Advanced media literacy Competency}

The skills to evaluate media messages

Based on the results of the analysis of data obtained by frekuentatif percentage figures of $62 \%$ of the skills scale evaluates the expected media messages (100\%). Percentage of the frekuentatif obtained from the analysis results from Figure 4 below.

Grafik Tingkat Kompetensi Literasi Berdasarkan Keterampilan Mengevaluasi Pesan Media

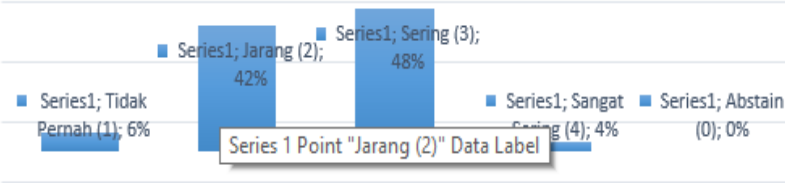

\section{Gambar 4 Persentase Frekuentatif Kegiatan Mengevaluasi Pesan Media}

Based on the graph in Figure 4, the collected data of $48 \%$ respondents said often in doing these activities evaluate the messages the media as media literacy competency beroerientasi description life skills. As for the details of activities that reflect the skills and competencies of the media literacy beorentasi life skills activities in evaluating media message, among them (1) assess the media based on the viewpoint of morality, with the percentage of frekuentatif of $68 \%$ (representation of social skills); (2) evaluate media content with discussing the along with colleagues or establishing, with the percentage of frekuentatif of $65 \%$ (the representation of social skills); (3) close the access to media that is not answerable morally, with a percentage of $60 \%$ frekuentatif (representation skills Polytechnic); (4) evaluate media content based on basic rules of applicable law, with the percentage of frekuentatif of $61 \%$ (representation of academic skills); and (5) evaluating the media refers to the study of the theory, with the percentage of $57 \%$ frekuentatif (representation of personal skills).

The skills of producing media messages

Advanced literacy competence this last one, excavated from the skill of producing media messages. Based on the results of the analysis of data obtained by presentation skills produce media content on a high school teacher of Bandung city, of $48 \%$ of the skills scale produces the expected media messages $(100 \%)$. Figure 5 here's a perscale percentage of rician frekuentatif activities producing the message media high school teacher of Bandung city.

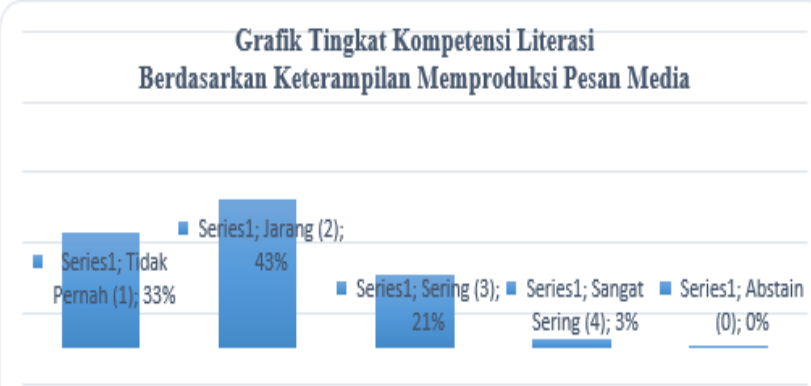

Gambar 5 Persentase Frekuentatif Kegiatan Memproduksi Pesan Media

Based on the graph in Figure 5, the obtained data on the percentage of frekuentatif activities producing the message media of $43 \%$ of the respondents stated rarely and $33 \%$ were either never in doing these activities produce the message media as media literacy competency beroerientasi description life skills. As for the details of activities that reflect the skills and competencies of the media literacy beorentasi life skills activities in producing media messages, among them (1) making media content (news, advertising, film, etc.) as a teaching materials and media, with the percentage of $70 \%$ frekuentatif (representation skills Polytechnic); (2) directing or assigning students to actively criticize media content either in the media or in social media, with the percentage of frekuentatif of $64 \%$ (Polytechnic prowess representation); (3) refer a writings from other sources into social media, with the percentage of frekuentatif amounted to 56\% (representation of social skills); (4) make the content of the media (article and video) to share information and knowledge societies, with the percentage $54 \%$ of frekuentatif (the representation of social skills); (5) making media content as material for research, with the percentage of frekuentatif of $48 \%$ (representation of academic skills); (6) writing argument essays or to criticize an content or media messages in print, with the percentage of $46 \%$ frekuentatif (representation of personal skills); (7) post a question in the discussion forum online (online), with a percentage of frekuentatif of $46 \%$ (the representation of social skills); (8) making critical reviews about the dissatisfaction of a media content and put it on a personal blog, with a percentage of $40 \%$ frekuentatif (representation of personal skills); (9) following the discussion in the interactive television by telephone, with the percentage of frekuentatif of $38 \%$ (the representation of social skills); (10) sent a video to the news media that open service journalist audience e.g. sending video news to broadcast news journalist citizens (citizen journalism), with a percentage of $34 \%$ frekuentatif (representation of academic skills); and (11) make a video on the internet (Youtube) on the impact of media content, with a percentage of $33 \%$ frekuentatif (representation of academic prowess).

The results of the analysis and research on data describing the level of competence of media literacy-oriented life 
skills Teacher SMA Bandung can be inferred that the Bandung city high school teacher is at intermediate literacy competencies with competency percentage of $70 \%$. This means that a fairly high level of awareness against the impact of the media (76\%) have not been followed by productive competence or in other words still exist in the user's tinggat or reactive media users have not been on proactive and productive conditions.

Type-type of media literacy-oriented life skills teacher Type of Media Literacy by type of Media

Types of media based on aspects of the access levels frekuentatif

Newspapers are still regarded as the most reliable information by HIGH SCHOOL teachers of Bandung in improving literacy competency. The use of newspapers and magazines is the interpretation that media literacy Teacher SMA Bandung still utilize literacy in terms of literacy. Table 1 below shows the frekuentatif types of print media that is often accessed by a high school teacher of Bandung city.

Table 1 Type of Print Media

\begin{tabular}{|c|c|c|}
\hline No. & The Type Of Print Media & The Percentage \\
\hline 1 & newspaper or newspaper & $89 \%$ \\
\hline 2 & Magazine & $57 \%$ \\
\hline 3 & Banners & $29 \%$ \\
\hline 4 & Posters & $25 \%$ \\
\hline 5 & Pamphle & $18 \%$ \\
\hline 6 & Other & $11 \%$ \\
\hline \multicolumn{2}{|c|}{ Source: research results (2016) } \\
\hline
\end{tabular}

Source: research results (2016)

Table 1 shows the level of frekuentatif the use of the media the media literacy skills information in terms of narrow, i.e. media literacy competency only deals against there is not access to electronic media (audiovisual) broadcast television and radio (audio), as many as $82 \%$ of high school teacher of Bandung were still using media information broadcast television as a medium that contribute to media literacy competence whereas for level frekuentatif the use of the media any information broadcast radio (audio) only amounted to $43 \%$.

Furthermore, table 2 below also shows the existence of a media literacy activity involving digital media. This means that the new media literacy has dominated the other informative media particularly the use and utilization of internet-based social networking media, whether it is site facebook, Twitter, Path, Instragram or application-based cell phone (smartphone) service providers and social networks such as Line or What'up. The dominance of digital media based social networking $(96 \%)$ defeats the electronic media such as television $(82 \%)$ and radio broadcasts $(43 \%)$. That is, respondents or high school teacher of Bandung now shifts do media literacy activities at the new media literacy.
Tabel 1 Jenis Media Elektronik dan Digital

\begin{tabular}{|c|l|c|}
\hline No. & Jenis Media Digital & Persentase \\
\hline 1 & internet: jejaring sosial & $96 \%$ \\
\hline 2 & siaran televisi & $82 \%$ \\
\hline 3 & $\begin{array}{l}\text { internet: surat-kabar online/website } \\
\text { newaspaper/web-paper }\end{array}$ & $82 \%$ \\
\hline 4 & internet: situs (website) resmi & $50 \%$ \\
\hline 5 & siaran radio & $43 \%$ \\
\hline 6 & e-paper: surat kabar atau majalah digital & $32 \%$ \\
\hline 7 & internet: situs (website) blog & $32 \%$ \\
\hline 8 & internet: situs (website) forum & $32 \%$ \\
\hline 9 & langganan berita daring (online) & $14 \%$ \\
\hline
\end{tabular}

Location type

Media access activity to enhance the competence of the media literacy figures obtained persetase, amounting to $54 \%$ for the access to media literacy in school, $35 \%$ for access literacy media in societies, and $34 \%$ for the access to media literacy in the home. The school as a main container activity of educators and learners already provide support for media literacy competency activities menfasiltasi.

Media literacy competency-oriented quality of life skills Based on the results of the analysis of data obtained a description of the percentage literacy competency quality media oriented life skills teacher high school in Bandung city amounted to $61 \%$ of scale quality of life skills-oriented literacy competencies expected (100\%). The amount of data for frekuentatif activities access, analyze, evaluate, and produce content or media messages is done by high school teacher of Bandung city of 2035. Thus, the percentage of quality media literacy competency-oriented life skills teacher HIGH SCHOOL in the city of Bandung as a whole amounted to $61 \%$ from the results of a comparison of the actual score (1580) with a score of ideal (3360)

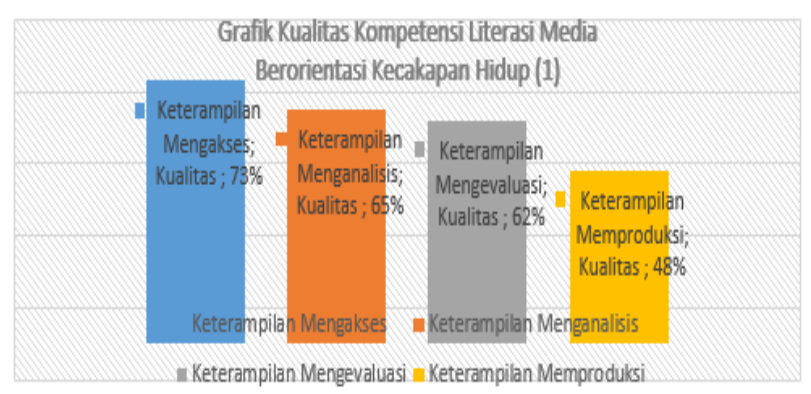
Gambar 6 Kualitas Kompetensi Literasi Media Berorientas
Kecakapan Hidup (1)

Based on Figure 6, can be seen the percentage dominance of mapping skills through activities that represent the life skills beorientasi literacy competence that owned Bandung city high school teacher, as much as $73 \%$ domination activities literacy competency skills to access media on the message or content of the media, then $65 \%$ of the activities of the media literacy competency skills at analyzing 
message content or media, $62 \%$ of the activities of the media literacy competence in the skills of evaluating the message or content of the media and only $48 \%$ of the activities of media literacy competence in skills produces a message or media content. That is, positive efforts are required in order for the high school teacher of Bandung was able to increase life skills beorientasi literacy competencies has to level productive.

Figure 7 shows the dominance of the Polytechnic in literacy competency skills of media oriented life skills for teachers of HIGH SCHOOL in the city of Bandung, amounting to $69 \%$. That is to say, HIGH SCHOOL teachers in Bandung are already making use of the media and media content to improve the skills specifically related to the teaching-learning process or learning.

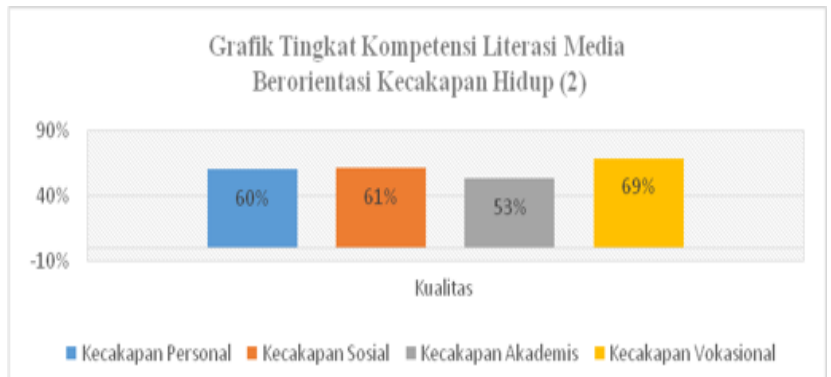

Figure 7 Berorientas Media Literacy Competency Quality life skills (2)

Factor endowments and restricting factors

A Supporting Factor.

Based on the analysis of data obtained a description of the factors supporting this as follows.

1. Sarana-prasarana in the media literacy competency.

One of them access to these kinds of media have already obtained easily either at school (work), in the environment (society), and the teachers have started to open up access to media messages at home personally. Access advice and this includes presence availability prasaran infrastructure both print media (newspaper subscriptions), electronic media (the existence of facilities such as television and radio elektornik), and digital media (internet) that can now be accessed at school, in the Community (public facilities), also in the House are even accessible for individual, personal, and private (Privacy).

2. Receptacle or teacher discussion forum regarding literacy competency.

The presence of colleagues or fellow to establishing who has the same focus in literacy competence in order to create a study group in kesalingan in the process of the transfer of science as well as ancillary skills literacy competencyoriented life skills for high school teacher of Bandung

3. Training that improves the literacy teacher competence.

Need for training-training for teachers in improving literacy competency. Pengingkatan literacy competence should in theory to a practical level so the ability, willingness, and media literacy competence can be up to level productive. Such training should preferably be organized regularly and periodically either organized by the Government, social agencies, colleges, and school/work place themselves with the aim of improving the competence of teachers professionally especially related to peningkataan kemelekan media and technology.

B. Factors Restricting

As for restricting factor of research data is (1) the limitations of the time teachers to perform the kegitaan self development especially improvement of media literacy competence so that high school teacher of Bandung city, so the high school teacher of Bandung city hasn't been able to memanfaatan media optimally and productive; (2) the burden of teaching and other work load. The large number of weights class and the service work that is delegated to a particular teacher high school teacher in the city of Bandung made the existence of the time limitations in the development of the self; (3) Yet the existence of a container or forum that is the focus of literacy competency enhancement mastered specifically for high school teacher Bandung; (4) the lack of a container or forum on literacy competence enhancement; (6) lack of penyelanggaran training, socialization, guidance or counseling regarding the competence of media literacy; and (7) the technical Constraints in the operation of various types of media in particular that based on ICT.

The availability of facilities and infrastructure supporting The internet access has been very accessible either in the school as a teacher's working environment, in society or in public facilities that can be accessed by the public, and now the internet is already a personal or private nature since it was already accessible on a cell phone belongs to. In addition to access to the media-based digital or new media, availability of pengeloaan internet filter that's been easy to come by so the protection or protection against sites not responsible can already was either constitutionally or by mail readers as a form of media literacy competence (a powerful mob) or social media facilities that can accommodate any complaints from the public to the providers of those services. Furthermore, access to the print media that is very adequate because print media particularly newspapers and magazines have become facilities obtained easily either at school, in institutions or companies of public service, many teachers who have already done the service personally against print media at his house each. Lastly, the availability of books supporting the literacy competence can be accessed in the public library or school library to the public.

\section{CONCLUCION}

Media literacy competency beorientasi life skills teacher SMA Bandung needs to be improved. Not only on the level of awareness of the impact of media on pengunaanya but it is up to the level of advanced media literacy competency. High school teacher of Bandung city already has a good awareness to the impacts generated by the media and has been conducting activities that can whet the media literacy competency. Although, dominance on activities that are in the competence of intermediate media literacy, i.e. activities to access and analyze media messages. Increased 
activities on the level of information is still required. This can be seen from the level of frekuentatif on activities evaluate to produce media messages is still low. A high level of awareness against the impact of the media has not been followed by productive competence or in other words still exist in the user's tinggat or reactive media users have not been on proactive and productive conditions.

Judging from the media type, high school teacher of Bandung is already using the new media messages. It is seen from the domination of the internet-based informative media use, which is intended to facilitate the social networking, whether it is site or application in the shape of a mobile phone (smartphone). This is due to the existence of the facilities and infrastructure that are accessible, community school (public service), and home. Teacher educators as a subject (role models) must be capable of being the subject of media users and users of proactive, reactive, and productive. Media literacy competency improvement quite urgent and indispensable that teachers can utilize media optimally to help pengoptimalkan the process of education and learning as well as an increase in self development in a professional manner. A good media literacy competency can help in menghindarikan themselves of dependence as well as the use of media that tends towards the negative or on things that can harm yourself or others arising from the influence of the media.

\section{REFERENCES}

[1] Amalia, R. (2013). Makalah Literasi Digital dan Literasi Media. Universitas Sumatera Utara Diakses dari: rizkiamalia.weebly.com

[2] Art, S. (1995). Media literacy: key to interpreting media massages. Publisher: Preager. USA.

[3] Baran, J. S. (1995). Mass communication theory: foundation, ferment, and future. USA: Wadsworth

[4] Creswell, John W. (1994). Research Design: Quantitative and Qualitative Approach. London: Sage Publications.

[5] Creswell, John W. (2008). Educational Research: Planning, Conducting, and Evaluating Quantitative and Qualitative Research. (third edition), Prentice Hall.

[6] Darmastuti, R. (2012). Literasi media dan kearifan lokal. Diakses dari: http://repository.uksw.edu.

[7] Dinas Pendidikan Kota Bandung. (2016). Rekapitulasi Passing Grade Kota Bandung. Diakses dari: http://ppdb.bandung.go.id.

[8] Irianto, Y. (2009). Literasi media. Bandung: Simbiosa Rekatama Media.

[9] Marwiyah, S. (2012). Konsep pendidikan berbasis kecakapan hidup. Jurnal Falasifa. Vol.3. Diakses dari: htttp://www.academia.edu.

[10] Peraturan Pemerintah Republik Indonesia Nomor 74 Tahun 2008 tentang Guru

[11] Potter, W. J. (2008). Media literacy $4^{\text {th }}$ edition. University of California, Santa Barbara. Sage Publication: Los Angeles.

[12] Rahardjo, T. (2012). Memahami literasi media: presfektif teoretis, Literasi media dan kearifan lokal: konsep dan aplikasi. Diakses dari: htttp://eprints.undip.ac.id.

[13] Sugiyono. (2013). Metode penelitian dan pendidikan: pendekatan kuantitatif, kualitatif, dan $r \& d$. Bandung: Alfabeta.

[14] Supriatna, M. (2007). Pengembangan kecakapan hidup di sekolah Diakses dari: http://file.upi.edu.

[15] Undang-Undang Nomor 14 Tahun 2005 tentang Guru dan Dosen. 